DOI: $\underline{\text { https://doi.org/10.53955/jhcls.v1i2.10 }}$

Published by Lembaga Contrarius Indonesia

This work is licensed under a Creative Commons Attribution 4.0 International License (cc-by).

RESEARCH ARTICLE

\title{
Application of Timber Legality Verification System (SVLK) Policy as Ecolabel Implementation in the Indonesian Timber Industry
}

\author{
Arifin Ma'ruf ${ }^{1 凶}$ \\ ${ }^{1}$ Researcher at Java Learning Center, Yogyakarta \\ $\bowtie$ arifindo78@yahoo.com
}

\begin{abstract}
Ecolabel is an international environmental standard that has been set by the World Trade Organization (WTO). The application of ecolabel is expected to be a solution for environmental problems. Ecolabeling is carried out with an approach of internationally agreed standards. In the timber industry in Indonesia, ecolabeling is implemented with the Timber Legality Verification System (SVLK) policy. This policy is proven to overcome illegal logging and illegal trade and improve forest governance.
\end{abstract}

Keywords: Ecolabel; SVLK; and Environment.

\section{INTRODUCTION}

The environment is one of the critical elements in the life of the world, so its existence is vital for humans and other living creatures so that this environment must always be maintained and preserved. According to history, the international community had long focused on paying attention to the environment, namely since the 1950s when environmental pollution occurred, especially in developed countries caused by mining industrial waste and pesticides, which then prompted the birth of the Stockholm Conference in 1972, so that at that time the issue of Regarding the environment, it is no longer a national issue, it is even a world concern, so that environmental problems are a global problem. ${ }^{1}$ The trade implications of economic globalization on the law cannot be avoided because legal globalization follows economic globalization, in the sense that the substance of various laws and agreements spreads across national borders (crossborder). ${ }^{2}$

One of the environmental issues discussed in the WTO forum is ecolabel, which is now known as an environmental standard. Ecolabel is a means to convey accurate, "verifiable" information and does not mislead consumers about the environmental aspects of a product

\footnotetext{
${ }^{1}$ Soemarwoto, Ekologi, Lingkungan Hidup dan Pembangunan, (Jakarta : Djambatan), 1991, p. 2.

${ }^{2}$ Erman Rajagukguk, "Globalisasi Hukum dan Kemajuan Teknologi: Implikasinya Bagi Pendidikan Hukum dan Pembangunan Hukum Indonesia,” speech on Dies Natalis Universitas Sumatera Utara Ke-44,
} 
DOI: https://doi.org/10.53955/ihcls.v1i2.10

Published by Lembaga Contrarius Indonesia

This work is licensed under a Creative Commons Attribution 4.0 International License (cc-by).

(goods or service), components, or packaging. These environmental aspects include "biodegradability" (easiness of materials to decompose in the environment), consumption of water or energy per ton of product, "recyclability" (easiness of materials to be recycled), toxicity (level of danger of being toxic to people or other biotas), and others. This ecolabel program aims to encourage the demand and supply of environmentally friendly products in the market while encouraging sustainable environmental improvements. ${ }^{3}$

In its meeting in Marrakech, the WTO has determined the acceptance of ecolabel as an international environmental standard as long as it is carried out in a non-discriminatory manner, transparency, and handling of environmental problems is carried out with a multilateral approach and as far as possible based on international standards. The 1994 GATT Agreement, the provisions of which relate to environmental issues, both contained in the Preamble, Body and Attachments, namely the Agreement Establishing the World Organization (Agreement on the Establishment of the World Trade Organization) Agreement on Agriculture, Agreement on the Application of Sanitary and Phytosanitary Measures, Agreement on Technical Barriers to Trade GATT The WTO has indeed paid great attention to the environment, and this is contained in its Agreements. However, it is suggested that the WTO should be able to make a policy in international trade that can accommodate the interests of environmental preservation and trade interests in a balanced portion.

Indonesia, as part of the world's citizens who have ratified the Earth Summit and has officially become a member of the WTO, the concern of developing countries regarding the implementation of environmental standardization is also a concern for Indonesia. For example, the provision regarding the ecolabelling/wood certification program, which is a policy that requires tropical countries to sign their wood commodities which guarantees that the product is produced without damaging the environment. ${ }^{4}$ In particular, the Indonesia ecolabelling/wood certification program has become a concern for wood entrepreneurs on the one hand because they have to ensure legal documents when they want to export in the timber sector on the one hand. However, on the other hand, the concept of a wood certification program is one solution to forestry, one of which is to avoid or prevent illegal timber harvesting or not according to legal procedures. Therefore, the existence of a legal umbrella $a^{5}$ for the ecolabelling mechanism in Indonesia concerning international trade is a standard that has relevance to import flows that trading countries must meet this standard to enter the Indonesian market in order to protect domestic consumers and ensure environmental sustainability. ${ }^{6}$

${ }^{3}$ Masnellyarti Hilman, Ekolabel, Standar Logo Bagi Produk yang Telah Memenuhi Persyaratan Lingkungan, Deputi Bidang Pembinaan Sarana Teknis Pengelolaan Lingkungan Hidup Kementerian Lingkungan Hidup, Jakarta, 2015

${ }^{4}$ Riadhi alhayyan, Syamsul Arifin, Jelly Leviza, Mahmul Siregar, Analisis Hukum Terhadap Standarisasi Lingkungan Dalam Perdagangan Internasional, USU Law Journal, Vol.3.No.3 (November 2015) p. 112.

5 Siti Djazimah and Muhammad Jihadul Hayat, Pelaksanaan Kursus Pranikah Di Kota Yogyakarta: Urgensitas, Efektivitas Hukum, Dan Tindakan Sosial', Al-Abwal: Jurnal Hukum Keluarga Islam, 11.1 (2019), 59-68 <https://doi.org/10.14421/ahwal.2018.11105>.

'http://www.hukumonline.com/klinik/detail/cl3266/pengaturan-ecolabellingdi-indonesia, accessed on 17 Desember 2016. 
Journal of Human Rights, Culture and Legal System, Volume 1, No. 2, 2021

ISSN (Print) 2807-2979, ISSN (Online) 2807-2812

DOI: https://doi.org/10.53955/jhcls.v1i2.10

Published by Lembaga Contrarius Indonesia

This work is licensed under a Creative Commons Attribution 4.0 International License (cc-by).

\section{DISCUSSION}

\section{Ecolabel is an International Environmental Standard}

The environment is one of the things that become the focus of international trade, but environmental issues are still often sidelined with other issues such as military threats and talks about trade rules. The existence of cooperation between countries is one solution to solving environmental problems. ${ }^{7}$ The international trade organization known as the World Trade Organization (WTO) was born and hopes to carry out international trade activities within a legal corridor that carries the principles of fairness and justice. ${ }^{8}$

One of the forms of implementing fair and fair principles is running a business by paying attention to environmental aspects. As the embodiment of the General Agreement on Tariffs and Trade (GATT), WTO aims at optimal utilization of natural resources to maximize the exploitation of natural resources. Therefore, in the utilization of natural resources, the role of the WTO in ensuring environmental sustainability is still needed. At the implementation stage, it turns out that the WTO also has a fundamental role in providing environmental protection. The WTO, in its provisions, stipulates that every WTO member country is obliged to consider the objectives of sustainable development and the achievement of protection against environmental conservation. The rights of WTO countries are also recognized to impose barriers or implement a system of trade restrictions related to environmental protection issues.?

Protection of the environment has already been regulated in the GATT Provisions, namely as stated in Article XX paragraph (b) stating...necessary to protect human, animal or plant life or health (needed to protect humans, animals or live plants or health); Then it is regulated in Article $\mathrm{XX}(\mathrm{g})$ relating to conservation of exhaustible natural resources if such measures are made effective in conjunction with restrictions on domestic production or domestic consumption). Article XX paragraphs (b) and (g) are the legal basis for the state to make environmental policies to protect human health and the environment and conserve natural resources. ${ }^{10}$ However, on the condition that in making the policy, it must not create discrimination in trade or covert Protection. In Indonesia, the implementation of environmental Protection as mandated in the GATT and WTO is as regulated in Law Number 23 of 1997 concerning Environmental Management in conjunction with Law Number 32 of 2009 concerning Protection and management of the environment, wherein these rules it is regulated related to the implementation of the instrument for preventing pollution and/or environmental damage as well as steps and rules related to the prevention and enforcement of the law by taking into account the aspects of transparency, participation, accountability, and justice. ${ }^{11}$

In addition, organic rules also appear under it, such as Government Regulation Number 82 of 2001 concerning Water Quality Management and Water Pollution Control, government regulation Number 27 of 1999 concerning Environmental Impact Analysis (AMDAL), Minister of Environment Regulation Number 2 of 2014 concerning the inclusion of Ecolabel logo and so on. The emergence of these regulations is evidence that the Indonesian government has carried

7 Iva Rachmawati, Memahami Perkembangan Studi Hubungan Internasional, (Yogyakarta: Penerbit Aswaja Pressindo, 2012), p. 213

${ }^{8}$ Christophorus Barutu, Ketentuan Antidumping, Subsidi Dan Tindakan Pengamanan (Safeguard) Dalam GATT Dan WTO, (Bandung: Penerbit PT. Citra Aditya Bakti, 2007).

9 Aerticle XX GATT

10 Syahlan, 'Effective and Efficient Synchronization in Harmonization of Regulations Indonesia', 1.1 (2021), $54-70$.

11 Arifin Ma'ruf, 'Legal Aspects of Environment in Indonesia : An Efforts to Prevent Environmental Damage and Pollution', 1.1 (2021), 18-30. 
DOI: https://doi.org/10.53955/ihcls.v1i2.10

Published by Lembaga Contrarius Indonesia

This work is licensed under a Creative Commons Attribution 4.0 International License (cc-by).

out its mandate in protecting the environment as mandated in the GATT and WTO provisions. One form of environmental protection is through the concept of ecolabeling. Ecolabel is a means to convey accurate, "verifiable" information and does not mislead consumers about the environmental aspects of a product (goods or service), components, or packaging. These environmental aspects include "biodegradability" (easiness of materials to decompose in the environment), consumption of water or energy per ton of product, "recyclability" (easiness of materials to be recycled), toxicity (level of danger of being toxic to people or other biotas), and others. This ecolabel program aims to encourage the demand and supply of environmentally friendly products in the market while encouraging sustainable environmental improvement. ${ }^{12}$

Widespread standardization worldwide is starting to take place rapidly but is still independent of environmental management. The environmental management and standardization movement emerged in the early 1990s. This is through the hard work of many individuals and organizations such as the International Organization for Standardization (ISO), British Standard Institute (BSI), American National Standard Institute (ANSI), and many other organizations in many countries. Many standards have been proposed in the incorporation of environmental management. ${ }^{13}$

\section{Timber Legality Verification Certificate (SVLK) as an Implementation Step in Indonesia for the Ecolabel Concept in GATT and WTO}

Currently, Indonesia's forest area is estimated to reach 120.35 million ha or about 65 percent of the land area. Forests and natural resources are essential natural resources for Indonesia, with a reasonably high contribution to export employment and local community income. Around 300,000 people work in the wood management industry, and at least 14,000,000 people depend directly on the forest. The Ministry of Forestry in 2009 revealed data that the production capacity of the timber industry exceeds the forest's ability to produce raw materials sustainably, both from HPH and HTI, which in turn stimulates illegal logging. Nationally, the current demand for logs (industrial installed capacity) annually reaches 63 million m3. Meanwhile, the production of logs from production forests is around 31.9 million $\mathrm{m} 3 /$ year. $^{14}$

Forest Products accounted for 11 percent of export revenues during 1994-1999. Despite the enormous contribution of forests to social and economic welfare, these benefits are generated without considering forest sustainability. The rate of forest destruction in Indonesia is tremendous, it reaches 1.6 million to 2.1 million ha per year. ${ }^{15}$ Based on the above problems, the concept of ecolabeling in the timber sector emerged to limit the use of wood as a material for furniture production and wood crafts. The concept of ecolabeling in the timber or forestry sector is called SVLK (Timber Legality Verification System). This system allows for the sale of wood, so there must be a legal verification document legalized by the authorized institution related to the origin of the wood. Timber Legality Verification System or SVLK is an ecolabel system in the timber sector that is used to ensure that wood products and wood materials are obtained or derived from sources whose origin and management meet legal aspects or in other words, what is

12 Masnellyarti Hilman, Ekolabel, Standar Logo Bagi Produk yang Telah Memenubi Persyaratan Lingkungan, Deputi Bidang Pembinaan Sarana Teknis Pengelolaan Lingkungan Hidup Kementerian Lingkungan Hidup, Jakarta, 2015

${ }^{13}$ W. Lee. Kuhre, Sertifikasi ISO 14001: Sistem Manajemen Lingkungan, (Jakarta: Prep.lindo, 1996), p. 7

${ }^{14}$ Departemen Kehutanan. 2009. Statistik Kehutanan Indonesia 2008. Departemen Kehutanan, Jakarta.

15 Colfer, C.J.P., dan Reksosudarmo, I.A.P, Kemana Harus Melangkah?, Masarakat, Hutan dan Perumusah Kebijakan di Indonesia, Edisi I, (Jakarta: Yayasan Obor) 2003, p. 
Journal of Human Rights, Culture and Legal System, Volume 1, No. 2, 2021

ISSN (Print) 2807-2979, ISSN (Online) 2807-2812

DOI: https://doi.org/10.53955/jhcls.v1i2.10

Published by Lembaga Contrarius Indonesia

This work is licensed under a Creative Commons Attribution 4.0 International License (cc-by).

meant by SVLK is a system that guarantees legal timber products. and comes from sustainable forests. The SVLK guarantee pattern comes from the legal aspect. ${ }^{16}$

According to Darmawan, implementing the ecolabel principle in the Timber Legality Verification Standard or SVLK is one of the systems used to improve forest governance towards sustainable forest management. SVLK is a tracking system that is developed in a multistakeholder manner to ensure the legality of timber sources circulating and traded in Indonesia. The timber legality system was developed to combat illegal logging and trade, improve forest governance, and realize sustainable forest management. ${ }^{17}$ The Timber Legality Verification System (SVLK) was born through the Minister of Forestry Regulation or Permenhut No. P.38/Menhut-II/2009 and then the Policy was refined until the Minister of Forestry Regulation No. P.68/Menhut-II/2011, then Permenhut No. P.45/MenhutII/2012, and subsequently revised again with the issuance of Minister of Forestry Regulation No. P.42/Menhut-II/2013 concerning the Third Amendment to Permenhut P.38/Menhut-II/2009 concerning Standards and Guidelines for Assessment of PHPL and VLK Performance on Permit Holders or Private Forests. $^{18}$

In addition to the above rules, the Minister of Forestry Regulation No. P.38/MenhutII/2009 and other related derivative regulations, the government introduces the Timber Legality Verification System (SVLK), which is carried out through regulations that set mandatory standards by business actors in the forestry sector from upstream to downstream production. The Policy was later refined by Permenhut No. P.68/Menhut-II/2011, after that it was revised with Permenhut No. P.45/Menhut-II/2012, and finally revised with the issuance of Minister of Forestry Regulation No. P.42/Menhut-II/2013 concerning the Third Amendment to Permenhut P.38/Menhut-II/2009 concerning Standards and Guidelines for Assessment of PHPL and VLK Performance for Permit Holders or on Private Forests and Regulation of the Minister of Forestry Number P.43/MenhutII/ 2014 concerning Performance Assessment of Sustainable Production Forest Management and Timber Legality Verification for Permit Holders or Private Forests, which were then followed by other regulations including Perdirjen P.8/VIBPPHH/2012 and also Permendag No. 64/M-DAG/PER/10/2012. The Timber Legality Verification System (SVLK) emphasizes the role of a more substantial representation of various stakeholders in tracking timber legality. The latest Policy is contained in the Minister of Environment and Forestry Regulation Number P.30/MenLHK/Setjen/PHPL.3/3/2016 concerning Performance Assessment of Sustainable Production Forest Management and Timber Legality Verification for Permit Holders, Management Rights, or Private Forests. ${ }^{19}$

The SVLK policy in 2020 was no longer enforced. The revocation of the SVLK policy was carried out through the Regulation of the Minister of Trade Number 15 of 2020 concerning Provisions for the Export of Forestry Industrial Products (Permendag 15/2020). The regulation expressly eliminates the obligation of exporters to verify the origin of products (SVLK) that they will sell abroad. ${ }^{20}$ On May 11, 2020, through Regulation of the Minister of Trade Number 45 of

${ }^{16}$ Redi Res, 'Implementation of Parate Executie Object of Liability Juridical Overview of Mortgage', 1.1 (2021), 42-53.

${ }^{17}$ Darmawan, A.H., NugrohoB., Kartodihardjo H,. Kolopaking L.M., Boer R, 2012, SVLK, Jalan

Menuju REDD+, Forest Governance dan Multistakeholder Forestry Programme, Jakarta, p. 2.

${ }^{18}$ Iswantoro, 'Strategy and Management of Dispute Resolution, Land Conflicts at the Land Office of Sleman Regency', 1.1 (2021), 1-17.

19 Abdul Kadir Jaelani and others, 'The Crime Of Damage After the Constitutional Court's Decision Number 76 / PUU-XV / 2017', 1.1 (2021), 31-41.

${ }^{20}$ Arifin Ma'ruf, Kebijakan Legalitas Kayu Untuk Keadilan, Buletin Legal Talk Vol. XII, September 2020, p. 5. 
DOI: https://doi.org/10.53955/ihcls.v1i2.10

Published by Lembaga Contrarius Indonesia

This work is licensed under a Creative Commons Attribution 4.0 International License (cc-by).

2020, the Minister of Trade officially revoked Permendag 15/2020. Thus, the SVLK provisions are re-enacted as one of the re-enactments of export provisions, namely by re-enacting the old Regulation, namely Minister of Trade Regulation 84 of 2016 concerning Provisions for Exports of Forestry Industrial Products. The SVLK concept is a soft approach effort from the government to improve good forestry governance over the rampant illegal logging, which damages the sustainability of forests and the environment and legal action (complex approach) that the government has used. The soft approach of the SVLK scheme has provided improvements to timber administration and administration using a mechanism that can be monitored by all parties and has credibility in its implementation or the field. ${ }^{21}$ SVLK covers upstream (timber-producing countries) and downstream (timber consuming countries) with the principles of improving better governance (governance), representation of the parties in its development and monitoring (representatives), and transparency (transparent) that can be monitored by all parties. Upstream, sustainable forest management is something that wood producers must fulfill so that the legality of wood is guaranteed downstream. In detail, the wood administration and procedures that wood producers must comply with at every wood movement are: ${ }^{22}$

1. Timber supply chain activities originate from state forests, starting from logging sites, timber collection points, timber stockpiles, and intermediate timber stockpiles.

2. Timber supply chain operations from private forest/land, especially at logging/timber collection points

3. Timber supply chain operations for industry and export in primary/integrated, secondary, and exports.

Management Units (UM) or business actors with SVLK are indeed required to comply with this to maintain the continuity of their timber business. The Management Unit (UM) or business actor who wants to care for the SVLK must go through a certification process. This process begins with the submission of a verification application addressed to the LV-LK. Moreover, by completing the required requirements as regulated in Permenhut P.38/MenhutII/2009 and P.68/Menhut-II/2011 in conjunction with P.45/Menhut-II/2012 Perdirjen number: P.8/VI$\mathrm{BPPHH} / 2012$ Appendix 2.1. In fulfilling the SVLK requirements, MUs must prepare human resources to become the team in charge and facilitate capacity building of the SVLK implementing team. After that, prepare the documents: ${ }^{23}$

1. Company legality; company establishment deed, an amendment to company establishment deed, company registration certificate, valid trading business license, NPWP, timber forest product utilization business permit (IUPHHK-HA or HT), business plan for timber forest product utilization, other documents related to attachment 2.1 Perdirjen BUK No P.8/VIBPPHH/2012;

2. Employment; labor list, collective work agreement document, work agreement document, statement not to employ underage workers, occupational health and safety, labor unions.

21 Buklet MFP NGI Mei 2012. “Cakrawala Baru Kayu Nusantara”. p. 17. http://nationalgeographic.co.id/p.aman/berkas/Buklet_MFP_NGI_Mei_2012.pdf

22 Rio Rovihandono. SVLK dan Tata Usaha Kayu Indonesia dalam Perjanjian VPA. Jakarta :MFP II. p. 3.

${ }_{23}$ Permenhut P.38/Menhut-II/2009 jo P.68/Menhut-II/2011 jo P.45/Menhut-II/ 2012 dan Perdirjen nomor : P.8/VI-BPPHH/2012 Lampiran 2.1. 
Journal of Human Rights, Culture and Legal System, Volume 1, No. 2, 2021

ISSN (Print) 2807-2979, ISSN (Online) 2807-2812

DOI: https://doi.org/10.53955/jhcls.v1i2.10

Published by Lembaga Contrarius Indonesia

This work is licensed under a Creative Commons Attribution 4.0 International License (cc-by).

3. Environment; plan for realization of environmental management and monitoring, which includes environmental impact analysis documents, environmental management plans, environmental monitoring plans, other environmental management documents following activities at the place of business.

4. Social; documents on the realization of social responsibility (CSR), minutes of delivery of social assistance, minutes of conflict resolution if there is a conflict, minutes of settlement of compensation, minutes of delivery of compensation;

5. Legality of logging; annual work plan (RKT) for the last three years, RKT work map, book, and recapitulation of the report on the results of the cruising f. Logging process; for the last one year and the current year includes reports on felling results, log mutation reports, other documents related to attachment 2.1 of Perdirjen BUK No P.8/VIBPPHH/2012 78;

6. Transportation; certificate of $\log$ validity, $\log$ transportation invoice, invoice, bill of lading, other documents related to attachment 2.1 of Perdirjen BUK No P.8/VIBPPHH/2012;

7. Training etc.; list of employees who have attended training, training plan documents, certificates of staff who have attended the training.

Wood or furniture entrepreneurs in Indonesia welcomed the existence of the SVLK concept in Indonesia. The research conducted by Ahmad Subulas Salam, Purwanto, and Suherman, with the title SVLK; One Type of Eco-Label to Control Wood Movement in the Furniture Industry in Jepara, concluded that furniture entrepreneurs agree with the existence of SVLK because it has a good purpose. For them, the most important thing is how to keep their business running and easy to get affordable raw material stocks. Because the SVLK is a multistakeholder initiative, it is hoped that the export of raw materials to foreign countries, both legally and non-legally, can be suppressed so that it will spur domestic industrial activities so that they can quickly get supplies of raw materials at a stable price.

\section{CONCLUSION}

The WTO has determined the acceptance of eco-labeling as an international environmental standard as long as it is carried out in a non-discriminatory manner, transparency, and the handling of environmental problems is carried out with a multilateral approach and as far as possible based on international standards. As the implementation of the ecolabel in the timber sector, the Timber Legality Verification System (SVLK) concept emerged. The system implemented in Indonesia was developed to combat illegal logging and illegal trade, improve forest governance, and realize sustainable forest management. Thus, the implementation of the SVLK requires the support of various parties so that it can be carried out correctly. 
DOI: https://doi.org/10.53955/ihcls.v1i2.10

Published by Lembaga Contrarius Indonesia

This work is licensed under a Creative Commons Attribution 4.0 International License (cc-by).

\section{REFERENCES}

Iswantoro, 'Strategy and Management of Dispute Resolution, Land Conflicts at the Land Office of Sleman Regency', 1.1 (2021), 1-17

Jaelani, Abdul Kadir, Universitas Sebelas Maret, Resti Dian Luthviati, Civil Registration, Study Program, and Universitas Sebelas Maret, 'The Crime Of Damage After the Constitutional Court's Decision Number 76 / PUU-XV / 2017', 1.1 (2021), 31-41

Ma'ruf, Arifin, 'Legal Aspects of Environment in Indonesia : An Efforts to Prevent Environmental Damage and Pollution', 1.1 (2021), 18-30

Res, Redi, 'Implementation of Parate Executie Object of Liability Juridical Overview of Mortgage', 1.1 (2021), 42-53

Syahlan, 'Effective and Efficient Synchronization in Harmonization of Regulations Indonesia', 1.1 (2021), 54-70

Djazimah, Siti, and Muhammad Jihadul Hayat, 'Pelaksanaan Kursus Pranikah Di Kota Yogyakarta: Urgensitas, Efektivitas Hukum, Dan Tindakan Sosial', Al-Ahwal: Jurnal Hukum Keluarga Islam, 11.1 (2019), 59-68 $<$ https://doi.org/10.14421/ahwal.2018.11105>

Buklet MFP NGI Mei 2012. "Cakrawala Baru Kayu Nusantara”. http://nationalgeographic.co.id/halaman/berkas/Buklet_MFP_NG I_Mei_2012.pdf

Christophorus Barutu, Ketentuan Antidumping, Subsidi Dan Tindakan

Pengamanan (Safeguard) Dalam GATT Dan WTO, Bandung: Penerbit PT. Citra Aditya Bakti, 2007.

Colfer, C.J.P., dan Reksosudarmo, I.A.P, Kemana Harus Melangkah?, Masarakat, Hutan dan Perumusah Kebijakan di Indonesia, Edisi I, Jakarta: Yayasan Obor, 2003.

Darmawan, A.H., NugrohoB., Kartodihardjo H,. Kolopaking L.M., Boer R, 2012, SVLK, Jalan

Departemen Kehutanan. 2009. Statistik Kehutanan Indonesia 2008. Departemen Kehutanan, Jakarta.

Erman Rajagukguk, "Globalisasi Hukum dan Kemajuan Teknologi: Implikasinya Bagi Pendidikan Hukum dan Pembangunan Hukum

Indonesia," pidato pada Dies Natalis Universitas Sumatera Utara Ke44.

http://www.hukumonline.com/klinik/detail/cl3266/pengaturanecolabelling-di-indonesia, diakses tanggal 17 Desember 2016.

Iva Rachmawati, Memahami Perkembangan Studi Hubungan Internasional, Yogyakarta: Penerbit Aswaja Pressindo, 2012.

Masnellyarti Hilman, Ekolabel, Standar Logo Bagi Produk yang Telah Memenuhi Persyaratan Lingkungan, Deputi Bidang Pembinaan Sarana Teknis Pengelolaan Lingkungan Hidup Kementerian Lingkungan Hidup, Jakarta, 2015.

Masnellyarti Hilman, Ekolabel, Standar Logo Bagi Produk yang Telah Memenuhi Persyaratan Lingkungan, Deputi Bidang Pembinaan Sarana

Teknis Pengelolaan Lingkungan Hidup Kementerian Lingkungan

Hidup, Jakarta, 2015.

Menuju REDD+, Forest Governance dan Multistakeholder Forestry Programme, Jakarta.

Permenhut P.38/Menhut-II/2009 jo P.68/Menhut-II/2011 jo P.45/Menhut-II/ 2012 dan Perdirjen nomor : P.8/VI-BPPHH/2012 Lampiran 2.1.

Riadhi alhayyan, Syamsul Arifin, Jelly Leviza, Mahmul Siregar, Analisis 
Journal of Human Rights, Culture and Legal System, Volume 1, No. 2, 2021

ISSN (Print) 2807-2979, ISSN (Online) 2807-2812

DOI: https://doi.org/10.53955/jhcls.v1i2.10

Published by Lembaga Contrarius Indonesia

This work is licensed under a Creative Commons Attribution 4.0 International License (cc-by).

Hukum Terhadap Standarisasi Lingkungan Dalam Perdagangan

Internasional, USU Law Journal, Vol.3.No.3 (November 2015).

Rio Rovihandono. SVLK dan Tata Usaha Kayu Indonesia dalam Perjanjian VPA. Jakarta :MFP II.

Soemarwoto, Ekologi, Lingkungan Hidup dan Pembangunan, Jakarta :

Djambatan, 1991.

W. Lee. Kuhre, Sertifikasi ISO 14001: Sistem Manajemen Lingkungan, Jakarta: Prehallindo, 1996. 